\title{
UJI MUTU JENANG KETAN DENGAN PENGAWET NATRIUM BENZOAT DAN TEKNIK PENGOLAHAN TERHADAP KETAHANAN PRODUK SELAMA DUA PULUH LIMA HARI
}

\author{
Ulfa Nur Maa'idah', Wilda Robita Awaliya ${ }^{2}$ \\ ${ }^{1,2)}$ Akafarma Sunan Giri Ponorogo, Jl. Batoro Katong 32 Ponorogo \\ e-mail: ${ }^{1)}$ ulfafarma@gmai.com
}

\begin{abstract}
Abstrak
Latar Belakang : Olahan jenang ketan yang beredar di pasaran belum menggunakan takaran bahan pengawet sesuai dengan peraturan BPOM No. No.36 Tahun 2013. Hal ini mendorong peneliti untuk melakukan berbagai uji coba guna menemukan teknik pengolahan jenang ketan yang tepat. Penelitian ini merupakan penelitian lanjutan, yang sebelumnya telah melakukan berbagai teknik pembuatan jenang ketan. Kemudian dipilih satu percobaan yang menghasilkan produk jenang ketan yang bertahan selama duapuluh lima hari berdasarkan pengamatan secara organoleptis. Tujuan : Untuk membuktikan bahwa teknik pembuatan jenang ketan dinyatakan layak, bukan hanya dari segi pengamatan organoleptis, namun juga di kuatkan dari hasil penelitian ALT dan AKK produk jenang ketan tersebut. Variasi pengamatan dari penelitian ini, terdiri dari dua cara teknik pengolahan yaitu dengan cara dikukus pada hari keenam dan cara tidak dikukus. Penelitian ini memadukan antara pemilihan teknik pengolahan pencampuran bahan-bahan pembuatan jenang ketan dan tambahan pengawet natrium benzoat sebesar $500 \mathrm{mg} / \mathrm{kg}$ bahan pada jenang ketan sehingga produk mampu bertahan selama duapuluh lima hari. Metode : Sampel yang digunakan olahan jenang ketan dengan takaran pengawet natrium benzoat 650mg diambil secara propotiorne stratified random sampling. Hasil : Kesimpulan dari penelitian ini bahwa uji organoleptis jenang ketan dapat bertahan selama duapuluh lima hari. Hasil uji ALT tidak memenuhi persyaratan dan hasil uji AKK memenuhi persyaratan sesuai dengan PERKA BPOM Nomor HK 00.06.1.52.4011 Tahun 2009. Simpulan dan saran : Hasil uji dari produk jenang ketan, yang sebelumnya melalui uji coba teknik pembuatan jenang ketan dengan penambahan pengawet Natrium Benzoat $(500 \mathrm{mg} / \mathrm{kg}$ bahan) berdasarkan PERKA BPOM Nomor HK. 00.06.1.52.4011 Tahun 2009, dapat dinyatakan sebagai teknik yang cukup baik dengan ketahanan produk hingga 25 hari berdasarkan hasil dari uji organoleptis, uji ALT dan uji AKK. Dapat dinyatakan bahwa pengawet Natrium Banzoat dengan takaran $500 \mathrm{mg} / \mathrm{kg}$ bahan, efektif sebagai pengawet pada jenang ketan, asalkan di olah dengan teknik yang tepat dalam proses pembuatannya.
\end{abstract}

Kata Kunci: Jenang ketan, Natrium Benzoat, Organoleptis, ALT, AKK

\begin{abstract}
Background: Processed sticky rice sticks on the market have not used a dose of preservatives according to BPOM regulation No. No. 36 of 2013. This encourages researchers to carry out various trials to find the right sticky rice processing technique. This research is a follow-up study, which had previously carried out various techniques for making sticky rice jelly. Then one experiment was chosen which produced sticky rice jenang products which lasted for twenty five days based on organoleptic observations. Objective: To prove that the sticky rice production technique was declared feasible, not only in terms of organoleptic observations, but also strengthened from the results of the ALT and AKK studies of the sticky rice jenang products. Variations in observations from this study consisted of two methods of processing techniques, namely by steaming on the sixth day and the way not steamed. This study combines the choice of mixing processing techniques for making sticky rice and additive preservative sodium benzoate of $500 \mathrm{mg} / \mathrm{kg}$ of material in sticky rice so that the product can last for twenty-five days. Method: The sample used in processing sticky rice with a preservative dose of sodium benzoate 650mg was taken by propotiorne stratified random sampling. Results: The conclusion of this
\end{abstract}


study is that the organoleptic test for sticky rice can last for twenty-five days. The ALT test results did not meet the requirements and the AKK test results fulfilled the requirements in accordance with PERKA BPOM Number HK 00.06.1.52.4011 in 2009. Conclusions and suggestions: Test results of sticky rice jenang products, which previously tested the sticky rice jenang making technique with the addition of Sodium preservative Benzoat (500mg / $\mathrm{kg}$ of material) based on BPOM's PERKA HK Number. 00.06.1.52.4011 In 2009, it can be stated as a fairly good technique with a product endurance of up to 25 days based on the results of organoleptic tests, ALT test and AKK test. It can be stated that preservative Sodium Banzoat with a dose of 500mg / $\mathrm{kg}$ of material, is effective as a preservative in sticky rice jelly, provided that it is processed with the right technique in the manufacturing process.

Keywords: Treat Sticky Rice, Sodium Benzoate, Organoleptic Test, ALT test, AKK test

\section{PENDAHULUAN}

Jenang merupakan makanan tradisional yang masih banyak menggunakan resep tradisional berdasarkan pengalaman. Jenang saat ini banyak dikembangkan dan dikemas lebih menarik oleh berbagai produsen makanan. Pada umumnya produk olahan jenang yang dibuat menggunakan takaran pengawet yang tidak sesuai dengan persyaratan yang berlaku.

Salah satu cara untuk membuat makanan jenang ini memiliki umur yang panjang yaitu dengan menggunakan pengawet dengan takaran yang tepat sesuai dengan peraturan yang berlaku berdasarkan PERKA BPOM No.36 Tahun 2013. Bahan tambahan pengawet yang di izinkan adalah bahan pengawet untuk mencegah atau menghambat fermentasi, pengasaman, penguraian, dan perusakan lainnya terhadap pangan yang disebabkan oleh mikroorganisme (BPOM, 2013).

Berdasarkan hasil wawancara yang dilakukan oleh salah satu produsen jenang di kabupaten Ponorogo, bahwasanya dari sekian jenis olahan jenang yang meliputi: jenang beras, jenang ketan dan jenang dodol, usia yang paling pendek terdapat pada jenang ketan. Maka dari itu, produsen jenang melakukan penambahan pengawet natrium benzoat dalam jumlah yang sangat banyak dengan acuan jenang ketan tersebut apabila ditambahkan pengawet natrium benzoat tidak berasa pahit. Oleh karena itu, dengan berdasarkan data tersebut, peneliti akan menambahkan pengawet natrium benzoat tidak melebihi batas persyaratan BPOM No.36 Tahun 2013 sebesar 500 mg/kg bahan.

Penelitian ini merupakan penelitian lanjutan, yang sebelumnya di awali dengan uji coba berbagai teknik pembuatan jenang ketan. Kemudian di pilih satu teknik yang tepat dan produk jenang dapat bertahan selama 25 hari yang ditinjau dari pengamatan secara organoleptis. Variasi dari teknik pengolahan tersebut adalah produk jenang di bagi menjadi dua bagian yang sama, yang pertama jenang di kukus pada hari ke-6 dan yang kedua tanpa di kukus. Sehingga untuk menyatakan produk jenang tersebut layak untuk di konsumsi dan memiliki mutu yang baik, tidak cukup dengan pengamatan secara organoleptis, namun di kuatkan dengan uji Angka Lempeng Total (ALT), dan uji Angka Kapang Khamir (AKK). Hasil penelitian ini dapat menguatkan teknik pembuatan jenang ketan tersebut, sehingga dapat dinyatakan sebagai teknik yang baik dengan hasil produk jenang bertahan selama 25 hari dengan takaran 
pengawet yang tepat, uji ALT dan uji AKK menyatakan layak untuk di konsumsi dan tidak membahayakan terkait dengan pertumbuhan jamur pada produk jenang tersebut.

Apabila hasil uji dinyatakan layak, maka teknik pembuatan jenang tersebut dapat di uji cobakan kepada produsen jenang dalam skala besar, dengan tingkat keawetan yang lama, maka dapat menambah nilai ekonomi produk dan wilayah edar yang lebih luas.

\section{METODE PENELITIAN}

Pada penelitian ini, populasinya adalah jenang ketan. Sampel yang digunakan adalah olahan jenang ketan dengan takaran pengawet natrium benzoat sebesar $500 \mathrm{mg} / \mathrm{kg}$ bahan. Teknik yang digunakan untuk mengambil sampel adalah proportiornate stratified random sampling. proportiornate stratified random sampling adalah teknik pengambilan sampel dari populasi yang memiliki anggota atau unsur yang tidak homogen dan berstrata secara proporsional (Sugiyono, 2007). Peneliti membuat jenis olahan jenang ketan dengan pengawet natrium benzoat sebesar $500 \mathrm{mg} / \mathrm{kg}$ bahan yang menggunakan teknik dikukus pada hari ke-6 dan teknik tidak dikukus.

Variabel bebas dalam penelitian ini yaitu olahan jenang ketan dengan tambahan pengawet natrium benzoat sebesar 500mg/kg bahan yang menggunakan teknik dikukus dihari ke-6 dan teknik tidak dikukus. Adapun variabel terikat dalam penelitian ini adalah uji organoleptis, nilai dari Angka Lempeng Total (ALT) dan Angka Kapang Khamir (AKK).

Jenang dengan mutu yang baik, tidak cukup dengan pengamatan secara organoleptis, namun di kuatkan dengan uji Angka Lempeng Total (ALT), dan uji Angka Kapang Khamir (AKK). Hasil penelitian ini dapat menguatkan teknik pembuatan jenang ketan tersebut, sehingga dapat dinyatakan sebagai teknik yang baik dengan hasil produk jenang bertahan selama 25 hari dengan takaran pengawet yang tepat, uji ALT dan uji AKK menyatakan layak untuk di konsumsi dan tidak membahayakan terkait dengan pertumbuhan jamur pada produk jenang tersebut.

Variasi dari teknik pengolahan tersebut adalah produk jenang di bagi menjadi dua bagian yang sama, yang pertama jenang di kukus pada hari ke-6 dan yang kedua tanpa di kukus. Sampel jenang ketan yang telah dibuat kemudian dilakukan uji pengamatan organoleptis selama 1 bulan untuk mengetahui rasa, tekstur, aroma serta tampilan hingga jenang tersebut keluar jamur dengan pengamatan secara visual. Adapun hasil uji organopletik pada sampel jenang dengan perlakuan tanpa dikukud dan dikukus pada hari ke-6 dapat dilihat pada tabel 4.1 dan tabel 4.2.

Sampel jenang ketan dengan kode A1, A2, A3, A4, A5, A6, A7 dilakukan uji ALT (Angka Lempeng Total) untuk mengetahui jumlah mikroba pada sampel jenang ketan. Sampel dengan kode A1 dilakukan pengujian pada hari ke-2, sampel dengan kode A2 dilakukan pengujian pada hari ke-6 dengan perlakuan tanpa dikukus, sampel dengan kode A3 dilakukan pengujian pada hari ke-6 dengan perlakuan dikukus selama 15 menit, sampel dengan kode A4 dilakukan pengujian pada hari ke-15 dengan perlakuan 
tanpa dikukus, Sampel dengan kode A5 dilakukan pengujian pada hari ke-15 dengan perlakuan dikukus selama 15 menit, sampel dengan kode A6 dilakukan pengujian pada hari ke-25 dengan perlakuan tanpa dikukus, sampel dengan kode A7 dilakukan pengujian pada hari ke-25 dengan perlakuan dikukus selama 15 menit. Masing-masing kode sampel dilakukan pengujian ALT (Angka Lempeng Total) dengan 2 kali pengulangan disetiap tingkat pengenceran. Hasil uji ALT berupa koloni/gram.

Sampel jenang ketan dengan kode A1, A2, A3, A4, A5, A6, A7 dilakukan uji AKK (Angka Kapang Khamir) untuk mengetahui jumlah kapang dan khamir pada sampel jenang ketan. Sampel dengan kode A1 dilakukan pengujian pada hari ke-2, sampel dengan kode A2 dilakukan pengujian pada hari ke-6 dengan perlakuan tanpa dikukus, sampel dengan kode A3 dilakukan pengujian pada hari ke-6 dengan perlakuan dikukus selama 15 menit, sampel dengan kode A4 dilakukan pengujian pada hari ke-15 dengan perlakuan tanpa dikukus, Sampel dengan kode A5 dilakukan pengujian pada hari ke-15 dengan perlakuan dikukus selama 15 menit, sampel dengan kode A6 dilakukan pengujian pada hari ke-25 dengan perlakuan tanpa dikukus, sampel dengan kode A7 dilakukan pengujian pada hari ke-25 dengan perlakuan dikukus selama 15 menit. Masing-masing kode sampel dilakukan pengujian AKK (Angka kapang Khamir) dengan 2 kali pengulangan disetiap tingkat pengenceran. Hasil uji AKK berupa koloni/gram.

\section{HASIL PENELITIAN}

Berdasarkan pengujian yang dilakukan di Laboratorium Mikrobiologi Akafarma Sunan Giri Ponorogo terhadap produk Olahan jenang ketan dengan penambahan pengawet sebesar $500 \mathrm{mg} / \mathrm{kg}$ bahan dapat dilihat dengan hasil data sebagai berikut:

\section{Hasil uji organoleptis}

Tabel 4.1 Hasil Uji Organoleptik jenang ketan tanpa dikukus

\begin{tabular}{ccccc}
\hline Hari & \multicolumn{4}{c}{ Keterangan } \\
Ke- & Rasa & Tekstur & Aroma & Tampilan \\
\hline $1-3$ & Manis & $\begin{array}{c}\text { Lembek } \\
\text { Kenyal }\end{array}$ & Khas jenang & Baik \\
& & Kenyal & Khas jenang & Baik \\
$4-14$ & Manis & Kenyal Bantet & Khas jenang & Baik \\
\hline
\end{tabular}

Berdasarkan tabel diatas bahwa uji organoleptis jenang ketan dengan perlakuan tanpa dikukus dapat bertahan selama 25 hari dengan organoleptis rasa manis, aroma khas jenang, tampilan baik dan tekstur lembek kenyal pada hari ke 1-3, kenyal hari ke-4 dan kenyal bantat dihari ke-15.

Tabel 4.2 Hasil Uji Organoleptik jenang ketan dikukus pada hari ke-6

\begin{tabular}{ccccc}
\hline Hari & & \multicolumn{2}{c}{ Keterangan } \\
Ke- & Rasa & Tekstur & Aroma & Tampilan \\
\hline $1-3$ & Manis & $\begin{array}{c}\text { Lembek } \\
\text { Kenyal }\end{array}$ & Khas jenang & Baik \\
& & Kenyal & Khas jenang & Baik
\end{tabular}


Vol. 8, No.1, Oktober 2019, hal 1-7

$\begin{array}{ccccc}\text { 6-10 } & \text { Manis } & \begin{array}{c}\text { Lembek } \\ \text { kenyal }\end{array} & \text { Khas jenang } & \text { Baik } \\ 11-14 & \text { Manis } & \begin{array}{c}\text { Kenyal } \\ \text { Kenyal Bantet }\end{array} & \begin{array}{c}\text { Khas jenang } \\ \text { Khas jenang }\end{array} & \text { Baik } \\ \text { 15-25 } & \text { Manis } & \text { Baik }\end{array}$

Berdasarkan tabel diatas bahwa uji organoleptis jenang ketan dengan perlakuan dikukus pada hari ke-6 dapat bertahan selama 25 hari dengan organoleptis rasa manis, aroma khas jenang, tampilan baik dan tekstur lembek kenyal pada hari ke 1-3, kenyal hari ke-4, lembek kenyal lagi dihari ke-6 dan kenyal bantat dihari ke-15.

2. Hasil Uji ALT dan AKK

Tabel 4.3 Hasil Uji ALT dan AKK

\begin{tabular}{|c|c|c|c|c|c|}
\hline \multirow{3}{*}{ No } & \multirow{3}{*}{ Hari ke- } & \multicolumn{4}{|c|}{ Jenis Uji } \\
\hline & & \multicolumn{2}{|c|}{ ALT (koloni/gram) } & \multicolumn{2}{|c|}{ AKK (koloni/gram) } \\
\hline & & $\begin{array}{c}\text { Tidak } \\
\text { dikukus }\end{array}$ & Dikukus & $\begin{array}{c}\text { Tidak } \\
\text { dikukus }\end{array}$ & Dikukus \\
\hline 1. & 2 & 397,5 & - & 10 & - \\
\hline 2. & 6 & $\begin{array}{c}\text { Spreader } \\
(>300)\end{array}$ & $\begin{array}{c}\text { Spreader } \\
(>300)\end{array}$ & 30 & 50 \\
\hline 3. & 15 & $\begin{array}{c}\text { Spreader } \\
(>300)\end{array}$ & $\begin{array}{c}\text { Spreader } \\
(>300)\end{array}$ & 25 & 20 \\
\hline 4. & 25 & $\begin{array}{c}\text { Spreader } \\
(>300)\end{array}$ & $\begin{array}{c}\text { Spreader } \\
(>300)\end{array}$ & 45 & 25 \\
\hline
\end{tabular}

Berdasarkan tabel diatas bahwa uji ALT pada hari ke-6 sudah tidak memenuhi persyaratan karena tidak bisa dihitung (Spreader). Sedangkan untuk uji AKK hasilnya memenuhi persyaratan karena pada pengujian hari ke-2, ke-6, ke-15 dan ke-25 baik dengan perlakuan dikukus ataupun tidak dikukus hasilnya tidak melebihi dari syarat yang telah ditetapkan yaitu sebesar 200 koloni/gram.

\section{PEMBAHASAN}

Olahan jenang ketan dengan komposisi bahan berupa tepung beras keatn $500 \mathrm{~g}$, gula merah $350 \mathrm{~g}$, gula pasir $250 \mathrm{~g}$, garam $10 \mathrm{~g}$, santan $700 \mathrm{ml}$, VCO $80 \mathrm{ml}$ dan pengawet natrium benzoat sebesar $650 \mathrm{mg}$ didapatkan hasil akhir jenang sebesar 1.497 gram. Uji yang dilakukan pada olahan jenang ketan ini berupa uji ALT, AKK serta uji pengamatan organoleptis selama 25 hari.

Pada uji ALT (Angka Lempeng Total) jenang ketan dengan perlakuan dikukus pada hari ke-6 ataupun tidak dikukus dilakukan dengan menghitung angka lempeng total pada tiap sampel. Hasil uji ALT yang dilakukan analisa dihari ke-2, ke-6, ke-15 dan ke-25 baik dengan perlakuan dikus ataupun tidak dikukus hasilnya tidak memenuhi persyaratan yang telah ditetapkan karena hasilnya spreader. Hanya pada hari kedua koloni yang tumbuh sebesar 397,5 koloni/gram. 
Pada uji AKK (Angka Kapang Khmair) baik jenang ketan dengan perlakuan dikukus pada hari ke-6 ataupun tidak dikukus hasil uji AKK menyatakan bahwa pengujian yang dilakukan pada hari ke-2, ke-6, ke-15, dan ke-25 hasil jamur yang tumbuh masih masuk dalam rentang persyaratan yang ditetapkan.

Keefektifitasan suatu pengawet seharusnya semakin hari semakin menurun dengan ditandai adanya nilai dari uji ALT dan Uji AKK yang semakin meningkat.

Adapun faktor yang mempengaruhi hasil yang tidak stabil dari pengujian pada pengujian hari ke-6 disebabkan oleh kondisi aseptis inkas yang kurang sehingga mempengaruhi hasil dari koloni yang tinggi. Dan pada hari berikutnya dengan cara kerja yang telah dibenahi memperoleh hasil koloni yang kembali stabil seperti yang di harapkan.

\section{SIMPULAN}

Uji organoleptis jenang ketan dapat bertahan selama 25 hari dengan keterangan rasa manis, tekstur kenyal bantat dihari ke-15, aroma khas jenang, tampilan baik. Jenang ketan tersebut terjadi perubahan tekstur jenang pada minggu kedua dengan keterangan tekstur berubah menjadi kenyal bantat. Hasil uji ALT (Angka Lempeng Total) dengan rentang waktu 25 hari pada hari keenam sudah tidak bisa dihitung (Spreader). Hasil Uji AKK pada sampel dilakukan di hari ke-2, ke-6, ke-15, dan ke-25. Hasil uji AKK disetiap pengujian dengan perlakuan tidak dikukus hasilnya sebagai berikut : hari kedua $10 \mathrm{koloni} / \mathrm{gram}$, hari keenam 30 koloni/gram, hari kelimabelas 25 koloni/gram, hari keduapuluhlima 45 koloni/gram. Sedangkan untuk perlakuan dikukus pada hari ke-6 hasilnya sebagai berikut: hari ke-6 50 koloni/gram, hari ke-15 20 koloni/gram, hari ke-25 25 koloni/gram.

Mutu jenang ketan berdasarkan uji ALT tidak memenuhi persyaratan sedangkan untuk uji AKK memenuhi pesyaratan sesuai dengan PERKA BPOM Nomor HK. 00.06.1.52.4011 Tahun 2009. Hasil uji dari produk jenang ketan, yang sebelumnya melalui uji coba teknik pembuatan jenang ketan dengan penambahan pengawet Natrium Benzoat $(500 \mathrm{mg} / \mathrm{kg}$ bahan) berdasarkan PERKA BPOM Nomor HK. 00.06.1.52.4011 Tahun 2009, dapat dinyatakan sebagai teknik yang cukup baik dengan ketahanan produk hingga 25 hari berdasarkan hasil dari uji organoleptis, uji ALT dan uji AKK.

Dapat dinyatakan bahwa pengawet Natrium Banzoat dengan takaran 500mg/kg bahan, efektif sebagai pengawet pada jenang ketan, asalkan di olah dengan teknik yang tepat dalam proses pembuatannya.

\section{REFERENSI}

BPOM RI. 2006. Uji Angka Kapang Khamir Pada Makanan dan Minuman. MA/60/MIK06. BPOM RI. BPOM RI. 2006 (2). Uji Angka Lempeng Total Pada Makanan dan Minuman. MA/60/MIK06. BPOM RI. 
Vol. 8, No.1, Oktober 2019, hal 1-7

BPOM RI. 2008. Pengujian Mikrobiologi Pangan. InfoPOM Badan Pengawas Obat dan Makanan Republik Indonesia (Volume 9), No 2. Maret 2008. BPOM RI.

BPOM RI. 2009. Penetapan Batas Maksimum Cemaran Mikroba dan Kimia Dalam Makanan. Jakarta: BPOM RI.

BPOM RI. 2013. Batas Maksimum Penggunaan Bahan Tambahan Pangan Pengawet. Jakarta: BPOM RI.

Badan Standarisasi Nasional. 1992. SNI 01-2986-1992. Dodol. Badan Standarisasi Nasional. Jakarta.

Fardiaz, S. 1989. Pengertian Kapang dan Khamir Mikrobiologi Pangan. Direktorat Jenderal Pendidikan Tinggi Pusat. Bogor: Ankas IPB.

Fakultas Kedokteran UGM Bagian Mikrobiologi. 1993. Dasar-Dasar Pemeriksaan Mikrobiologi. Yogyakarta: Fakultas Kedokteran UGM Bagian Mikrobiologi.

Irianto, K. 2006. Mikrobiologi Menguak Dunia Mikroorganisme (Jilid I). Bandung: Yrama Widya.

Kurnia, N. et al. 2016. Uji Kualitas Mikrobiologi Jenang Ditinjau Berdasarkan Angka Lempeng Total (ALT) Koloni Kapang Untuk Penentuan Daya Tahan Simpan. Malang: Universitas Muhammadiyah Malang. 